\title{
The Destructive Cult, the Cause of Formation, Nature and Countermeasures
}

\author{
Tian Xiang, Ma \\ Wuhan University, Wuhan, China
}

\begin{abstract}
The destructive cult is an underworld gang organization with the witchcraft and anti-social characteristics, in "The living god”, namely the gang master, as the faith. The cause of formation bases on mankind cognitive level and social environment except for artificial factors. So in any time, the destructive cult has the possibility and necessity of its existence. In paper, it emphasizes that we should strengthen scientific education, open mind and sublimation of self at the same time of improving society. In this way, can only we eliminate the influence of the cult, break down the foundations of the cult.
\end{abstract}

Keywords: destructive cult, witchcraft, gang, limit, limitless

Religion is the help of the heart. Namely, the expansion of cognitive ability, beyond limited, comprehend infinite, and even hold infinity, in order to achieve a reasonable process of the ultimate value of life. That is to say, it is human innate, and each person's fate is closely related to happiness, the ultimate existence of cognitive mental world.

Cult is different, although this concept is not appropriate, but so far, it is widely recognized by the public, mainly refers to the personal worship. That is "The living God" faith as the core, try every trick to mislead the public. And, to the anti social characteristics, this is the nature of the gang organization containing witchcraft. political nature, witchcraft, underworld gang are the salient features of the cult. International calls this phenomenon the cult (cult group, destructive cult, in today's society can be heard without end). Small scale, influence is also very small. But its destructive effect, on the social and human life of this still can not be overlooked.

With the help of the cognitive ability of religion is expanding, is the pursuit of understanding some ultimate. Feature is the ultimate and non utilitarianism, the direct achievement of cultivate personal disposition. With the help of the cult is deception, and set up by deception faith community, the purpose is the reality of the relationship-the money and the power, is political and disruptive.

\section{The Cult of the Causes}

According to the above, we can see, the generation and existence of cults, except for human factors, for example, some people have an evil intent towards, claiming to be "god", through various means. For example, in this kind of deception under witchcraft, deceive the world. There is also the objective reality of the factors, it is people's cognitive level and social environment. To sum up, it is the culture. So, in terms of causes,

Tian Xiang, Ma, Ph.D., Professor, China Buddhism and Buddhist Art Research Center, Wuhan University.

Correspondence concerning this article should be addressed to Tian Xiang, Ma. E-mail: universitywh@163.com. 
whenever, the cult has the possibility and necessity of its existence, there is a profound social soil, to determine the conditions of existence that are limited and unlimited.

\section{[ONE] Limited and Unlimited}

For humans, people's living space is limited, our knowledge is limited, cognition of nature, society and life is limited, and the objective reality is far more than our limited existence. This is the infinite, but also the fundamental question of religion.

1. The existence of contingency. By chance, the inevitable and free

Our ideal is to promote the development of the human society from the inevitable kingdom to the realm of freedom. But in fact, we have to face the accidental. Necessity, liberty and contingency are the important issues of human beings' thinking about the limited and unlimited... Although it is passive to accept, but through the efforts can grasp, so that man can conquer nature, human effort is the decisive factor, but one thing is that people choose, the success lies in God, so we have to pursue the realm of freedom. Only to choose things that human beings itself, the success also lies in the stage of human, is the ideal state of the realm of freedom, so the ultimate concern is religion.

The necessity is inevitable. Freedom is the ideal and the pursuit of freedom. As a matter of fact, the limited nature of human beings decides that human beings can not realize the ideal of the free kingdom. It is difficult to reach the realm of necessity to handle very skillfully. Whether it is the nature of the myriads of changes, amidst the winds of change of social life, and say for mankind's own mysterious. They are not only very powerful, and there are too many accidental, unable to grasp, in order to make human beings into the unobservable. Can not grasp the contingency. Let me put it in another way, the human condition is not inevitable, more than freedom, but by accidental! Must be able to grasp, freedom is our pursuit; unpredictable, can not grasp the chance to bring people the frustration and fear. We do not know when there will be a devastating earthquake and every kind of natural disasters, we do not know in the social life and the failure of the ups and downs of prosperity. But can not grasp their own destiny and the life and death. But, humans, are still hoping to get rid of by accident, hope beyond the limited existence and freedom to enter. As is, trying to get rid of accidental, beyond the occasional limited, as the ultimate pursuit, it is the fundamental religion. From the cause of the cult, religion is roughly the same. But, the cult of the generation, but that is in the accident, in confusion and fear, some people have an ulterior motive, with the help of witchcraft, claiming to be God, fradulent. Anything can be said for reversal of heaven and earth, movers and shakers, the grantor of salvation can avoid disaster, could be immortal, and so forth, the ultimate concern and illusory Co. request, and to induce aggregation of partially hope in chance get relief and eliminate the fear of the people to form a gang nature worship group, clique for personal gain.

Obviously, religion is to go beyond the pursuit of unlimited, generation of cult is the infinite pursuit became limited utility, not relying on the cognitive ability of expansion, but witchcraft and all kinds of tricks and the gang organization form. The method of destruction, has a political purpose, and the gang has three typical characteristics of the cult.

2. Material and desire-The lack of material

In the past, we believe that the material development, all the problems will be OK. Now is not the case, people have a desire for nothing more than fame, success and seeking survival. The continuous development of the material world, raising the level of human life seems to improve the human sense of happiness, but not 
entirely so. No matter how development, no matter what the degree of material, and people's desire to compare, the material is always scarce. Because of this, the material world is always full of temptation, and the greatest weakness of the human being is not to be tempted. Whether rich or poor, meal or hungry, have clothes to wear, or naked, as long as it is indulge their lust, especially as material interests above all else, above the moral self perfection, material will become the slaves, but could not resist material temptation, not matter the pressure. Cult group leaders know the weakness of human, not only disguise themselves as gods, calm the human and give human very small interest. Put some people in the desire to gather around, as their members, to further form the Cult group.

3. The relationship between man and nature, society. Human being's tiny and fragile

As human beings, in the face of strong natural, facing the constantly changing society, we can not grasp the nature, also can not grasp the society and destiny. As a human, in the face of strong natural, face the vicissitudes of the society, we can't grasp the nature, the same can not grasp the social and unable to grasp their own destiny. In contrast to the powerful nature and society, people are always small and vulnerable. In the powerful nature and society, everyone at best can only be in the sea of millet, alpine a handful of dust. Therefore, vulnerable individuals, total hope by the force of the group round his dream, realize the self survival. Once making friends carelessly, going astray, cult leaders psychographic, offer to help, or to deter him, or lure him, or to disaster threaten him, such humans also the unexamined into a member of cult.

It is based on limited existence, and the infinite pursuit of transcendence, contingency, and lack of human frailty based, determine the universality of religion, and the possibility and inevitability of the generation of a cult. On chance, we are unable to grasp, harbor fear; to desire, unable to meet, people always want to lead pursuit of material enjoyment. In the face of a strong natural and social, the vulnerable people always want to continue to seek the living space. These are the cults generated in the soil.

\section{[TWO] The Type of Unlimited Response, and the Cause of the Cult}

The development of science, whether it is the development of human science, or the development of natural science, including other ideas, and the above three aspects have a great relationship.

In the face of casual, lack and fragile, the attitude of the human being generally has three kinds:

First, as Confucius said, just listen. So, don’t talk about some magic power, “A gentleman who does not know something is not speech”. Don't know the things you don't say. Can not grasp the thing, do not do. No according to the thing not to do, don't say no according to the words. Everything to be in the future, this is a cautious attitude, but also the objective of the method. Here the full expression of the Chinese Confucian ideology of the spirit of realism, that is usually said of the Confucian world accession, is also the Confucian non religious theory basis.

Second, is the exploration of unlimited efforts. Pursuit of progress, getting rid of limitation, to develop cognitive ability, knowledge of the infinite, gradually become infinite for limitation. Active exploration and practice, and strive to get rid of by chance, grasp the inevitable, into freedom. The history of mankind, in fact, is the unlimited evolution into a limitation. For example, look at the bright moon. The moon is cloudy and sunny. It may not always be complete, before I saw it, that it is a pure and beautiful world: Chang'e, Wu Gang, the laurel, the small white rabbit, the hazy moon and the clear shadow, giving person a infinite daydream. The progress of science, human landing on the moon, the moon from infinity becomes finite after, human beings have a new understanding: No Chang'e, Wu Gang. Jade Hare, similar to these myths, there are not so many 
unspeakable mysteries. The distant moon into human territory, and understanding to the human body and diseases such as medicine. In the continuous deepening, in the continuous progress, an incurable disease such as tuberculosis like, everything is under the control of modern medicine. Natural science is the thing that makes infinite existence become limited. The same is true of human science, to understand, and to solve these problems, or unlimited direct conversion to limitatiom. This is undoubtedly the scientific attitude, scientific method.

Third, is to confuse the world with magic. Of course, there are a few people who have an ulterior motive. According to their own needs to speak casually, the God of a personality that is very specific and has a specific function, self say believe in yourself, and make up all sorts of lies. They can only use the existence of the occasional, the lack of material, human vulnerability; use this chance to deal with living in fear, the use of the material demand desire, as well as human being's tiny and fragile, to the living God as a deterrent. In order to witchcraft as cheating, the gang as a constraint, the implementation of his scheme. They arbitrarily fabricated, they regarded themselves as the "God of surrealism, and told those followers: I am the living God created everything, supernatural, claiming to be able to control everything." In order to confuse the masses of the people. For example, the doomsday theory. In fact, preach eschatology is not their objective, it's important to tempt the crowd, let people believe they can save the world in the end times, can lead you out of the end of the world. Therefore, those who are deceived become confused and unable to deal with, every day anxious and worried, eventually the chaos. In order to achieve the purpose of their fish in troubled waters, disturbed society. These people are talking nonsense, his mouth will read to: I am God, I am God possessed, on behalf of God, I come to save you. For ordinary people speaking, accidental, fragile and short, these are unable to solve; in the face of strong natural, ever-changing society, they are difficult to grasp, so feel very helpless. So, the lack of objective spirit, scientific attitude and correct knowledge, people want to change and change, and the fragility of the lack of chance, so easily deceived, to be coerced into the cult. The cult is generated and developed in such conditions.

Need to explain, the religious institution, such as Taoism, Buddhism, Christianity, Islam, actually has a dual nature. On the one hand, to carry out rational exploration, showing their ultimate concern, on the other hand, in order to survive, in particular will be by witchcraft nature, to allow people to attach importance to the supernatural. Such as in Taiwan, most of the Buddhist preach Buddhism philosophy and Buddhism thought, the Buddhism history, but there are also promote Shenshui can cure, can save a life. Can ward off evil spirits, can avoid the disaster, in order to attract believe people, leading to more and more people to follow. In fact, many Buddhist temples have such "blessing of water", but not deliberately propaganda. Even so, it is only for their own development, the community does not have a destructive.

\section{[THREE] Witchcraft Means, or Method}

All the evil cult, all have the sorcery character. They to witchcraft, swagger through the streets, by means of the method, control of believers. Its purpose is nothing more than this: To absurd enrichment, cheating, cheating the color, large is spread fallacies to deceive people, create chaos, social challenges and coveted artifact. Witchcraft truth is that the art of deception. Specific practices, generally have three: first, in order to guide the worship of believers, believers of strong faith, or claiming to be God, drop from the clouds; or possessed, soul attachment, with some witchcraft, people believe that he is God. So, causes and consequences of the omniscient; back from the dead, omnipotent, in short, is a powerful role, has the supernatural ability, is 
Superman. Do not know the inside story of the followers, pregnant with fear and awe cautiously, footsteps, not the Leichi half step. Followed by the temptation of interest. Do they like things, with the temptation of money, or temptation; even nonsense, the afterlife Fushou stretches. In short, you want what have what, such as some cult preaching in the end of the world can lead you to another world, exempt from disaster. And so on, with the temptation of interests, to make them become a sincere follower. Third, the use of disaster warning human beings, this means is the most vicious, let a person with fear, have to succumb to its power. To say that he is a superman, has boundless power; it is the supreme, not offensive, supernatural God, or to destroy the world in an instant. If they do not listen, there will be misfortune, there will be a big disaster, will die! Or use the so-called power law, or a specific function, wounding thousands of miles away, leading to death. In fact, it's a vicious curse. All of these, people have to scare people, threatening letter, have to follow, in order to gather, grow the worship team.

By induction, deception, intimidation, is such a despicable means, so many people lost themselves, become a vassal of these swindlers tools and disturb social peace.

In fact, the witchcraft has always been. The past exists, there is now, there will be not only in China, but also in foreign countries. Witchcraft scourge of mankind and the world, examples are too numerous to mention. "The case of witchcraft from the Han Dynasty to the Sui Dynasty", "ghost cat mystery"; from the Han Dynasty law regarding the severe punishment of the rules of witchcraft, to Ming Dynasty legal sanctions witchcraft laws, can see, witchcraft and anti witchcraft struggle often occur. As early as in the spring and Autumn period, it has been pointed out that: "With a false divination, strange skills, witch curse heresy, not auspicious demon and confusion words, false illusion of phase confuse good people, the king must try to check to this kind of behavior”. From ancient times to now, Chinese dynasties are considered witchcraft as heresy is an anti social strength, therefore all advocated the witchcraft containment, removal of witchcraft.

For example, "Han Feizi" was dedicated to the king the deathless medicine. The palace guards took his medicine to swallow, Chu was furious, want to kill the guards. The guardian said: "since it is not the dead, the king still want to kill me, so this is the death of the drug.” That magic influence so widely, the damage caused by large, and in the long history of human struggle. And if: Ximen Bao arrived in Ye County, the old gathered local people, asking them about people miserable. These people said: "to find the daughter-in-law, for this reason.” Ximen Bao asked why, replied: "Ye County officials annually to accumulate wealth to tax people, up to millions, they used only one of the hundreds of thousands of Rehoboth to marry a wife, and the witch with the rest of the money." Time to marry a wife, witch will find small small family woman, "said the woman for the daughter-in-law". Immediately under the dowry to marry. To give her a bath shampoo, give her a silk flower clothes; and for this in the river to her do the house, hang up red and yellow and red silk account, this woman lived there, to her banquet. Such after more than ten days, and everyone together decorative bed pillow, let the woman sitting on top, then let it floating in the river. On the surface of the water, floating on the water, floating in a few tens of sank. Those are people of a beautiful woman, for fear of being destroyed the witch, so most of the people with his daughter far away. Therefore, the city more and more empty, more poverty, this situation has continued for a long time. The people around all: If you do not give the bride, there will be a flood disaster, the people are drowned. Ximen Bao said: "To Rehoboth to marry a wife to officials, the witch, and the old people to the river to send the bride, I also want to send the woman.” These people say, "good”, to marry a wife for the day, to meet with the elders of Ximen Bao river. Officials, rich and powerful people, are gathered here, the witch is an old woman, is seventy years old. The apprentice has a dozen people, are wearing silk 
clothes, standing in the back of the old witch. Ximen Bao said: "Bo's wife called to come over, I have a look she looks beautiful.” People hold the woman out of the screen immediately. Ximen Bao looked at the woman back to officials, witches, people said: "This woman is not beautiful, the Witch of the trouble for me to the river to acquaint the Rehoboth, need to find a beautiful woman, a few days later sent her to.” Call the guards together to pick up the big witch, threw her into the river. After a while, said: "Why do you go for so long? Ask her to urge her!” And threw her one of her disciples into the river. And after a while, said: "This is the disciple why so long? To send a person to urge them!” And throw a disciple into the river. In total, three disciples. Ximen Bao said: "The witch, the apprentice, these are women, can not make things clear. Please state the situation for me." And the officials left the river. Ximen Bao bent, Yasukyo Keita, facing the river stood waiting for a long time. Officials, etc. in the next to look at the fear of panic. Ximen Bao said: "The witch, officials do not come back, how to do?" Want to send an official to the river to urge them. These people are scared prostrate on the ground, head is broken on the forehead, blood on the ground, pale as ashes. Ximen Bao said: "Well, wait a little longer for them to stay.” After a while, Ximen Bao said: "Officials can get up and look where the river Earl Liuke to stay long, you are spread it, leave here and go home.” Ye County officials and the public are very panic, since then, not to mention the thing for a wife.

Witchcraft but so, cited allegory and historical facts, is obviously the magic absurd ruthless whips and wonderful irony. However, the patient has been in witchcraft, multiply, still won't get in by every opening, attenuation. Therefore it can be said that even the scientific development of the present, with the magic of the nature of the cult, it still has its social factors, psychological factors, and the cult of the fight is actually a long-term work, but also can not be ignored. As long as human beings can not get rid of accidental, grasp the inevitable, into the freedom of the word, the cult will happen, it will not disappear.

\section{Cults and Gangs}

\section{[ONE] Culture and Advanced Culture}

What is culture, simply, culture is the symbol of human's recognition of nature and society. Therefore, the formation of culture has its historical conditions, and its regional conditions. Forming a closed culture in a closed area. With the opening of the region, such as printing, telecommunications, transportation, etc., such a closed geographical pattern was broken, the culture has gradually emerged in the state of integration. History forward development, culture is also the times. Some people say that China's culture, in 2000 has reached the level of today, has been in the forefront of the world. However, to modern times, China is lagging behind. Many people believe that China's backwardness is because of the backwardness of the culture, or that the cultural backwardness led to China's overall backwardness. I think it is not the case, and put forward the concept of "non culture". Special emphasis: it is not the Chinese culture, which leads to the non-culture. Such as war, the history of China's regime change is about three to five years, seven or eight years, more than 20 years, but in modern times from the 1644 A.D, the Taiping Heavenly Kingdom, the Opium War, has been to the northern expedition, the war, after more than a century of unstable factors, economic why to develop. Why is the country strong? In 1993, put forward a point of view, if to China 50 years of stability, will be able to rank highest in the world, and their meaning is in the description of the advanced sex of the Chinese culture. In fact, not 50 years, just 10 years, China has been at the forefront of the world. Obviously, Chinese culture, in essence, is a kind of advanced culture. 
Advanced culture must have several conditions, one with a long history and tradition, a deep culture of precipitation, there is a kind of advanced social awareness. Of course, it is determined by the existence of the economy, production relations to determine the shape of the culture. However, this culture is not unilaterally determined, and it must have a leading consciousness.

Advanced culture must be the culture of keeping pace with the times. Any culture, including our Confucian culture, Taoist culture, and Western culture, Christian culture, must meet the requirements of the times, reflect the characteristics of the times, and become a symbol of the spirit of the times. If you can not keep pace with the times, be an anachronism, such a culture cannot be called advanced culture. Therefore, advanced culture is the times. If, say, a country, there is no advanced culture, cannot say for the country, can only be called tribes, an organization without advanced culture, can not be said for the organization, can only be called the gang; a no forces of advanced culture, is not for the army, can only be called outlaw. That is to say, any individual, especially the group must have advanced culture as a guide, can be called advanced organization, advanced countries, advanced military.

\section{[TWO] Economic Development, Life Improvement, Culture is Lagging Behind}

Economic development, material living standards continue to enrich, coupled with the closure of the geographical pattern, in the network, and other modern media, the culture is diversified development trend. In the multicultural development, there are too many dregs, and the disproportionate to the advance of the times. The culture of some decadent culture, behind a stirring among the dry bones. In the current situation, the performance of a lot of outstanding is the popular culture. Here is not to say that the mass culture is not good, but there are a lot of dirty things really do with the mass culture as the carrier, the tenacious performance of his decadent and backward. Not to emphasize the class struggle now, but to put a lot of backward things into our social life. For example, literature and film and television works are claiming the ancient emperor and busy, hardworking Edmonton; loyal righteous servant and grateful, to life quest; slave owners between the rich and the poor of Freemasonry, brief encounter, concubines, jealousy, molesting gentlewoman, seduce a married woman; public occasions, flirting; in the past feudal society, capitalist society, cast aside the things, in today's society dregs, take delight in talking about. All of these things are to be pushed onto the stage by mass culture. In the past, some vulgar yellow things, mostly in the flea market. Today, network and media developed, the original stall culture moved to the public life, with the spread of modern media, openly sexually explicit, entered the hall of elegance. This is a very worrying phenomenon. Gang culture, witchcraft cult is in such an atmosphere, by means of mass culture this move, clamoring for a while.

The cult, essentially it is a gang, the so-called culture, also just gang culture. Mass culture is its transmission; vagrant is the backbone of the gang culture. Part of the youth, and some of the refugees are prepared to force gang culture. If public opinion without the correct guidance, advanced culture is the mainstream culture, will inevitably lead to spread of gang culture. Nowadays, rising in the ideological and cultural fields evil, bloody flavor too strong, erotic flavor too strong, wild flavor too strong, vulgar taste too strong! Such a situation, can not be said to be leaving the formation space as a cult, consciously or unconsciously, drive the fish into deep waters, the sparrows into the thickets.

Gang culture essence is privately owned by the family culture, the culture is in the means of production, relations of production private ownership foundation and the formation of an extreme egoism. Advanced culture is to keep pace with the times, tend to the public. Our family is also in constant socialization, the 
socialization of production mode and the way of life. Family culture, nature is patriarchal, is in the interests of the family as the core of culture, this to the private possession for cultural characteristics, in the gang has been fully embodied. The cult gang as a possession of the family, the implementation of personal dictatorship and the patriarchal system. The red, green is the gang, is pursuing gang culture. The characteristics of gang culture is closed, extreme egoism. Advanced culture is to serve the community, service the entire human. Gang culture is to serve it in this small group, therefore, extremely exclusive of egoism. Well, first of all, is to actually benefit parents, Li Gang leader. The cult leader actually is the big brother is tribal chief, is commanding the parents, everything is the only he is life all his interests as the center. Cult members are also selfish.

This self-interest has a significant feature, is the ambition, power, and therefore, we must rely on external forces to grow their own, expanding influence. So, take refuge in the alien, she Qiurong, is often a traitor culture. This is also the general characteristics of the cult. In foreign countries, cult in the ideology and culture is also subject to legal restrictions, so, fled foreign cult only in some people with ulterior motives captive fawning. They put dress themselves up as innocent victims, in their usual way, have forged a lie, and all kinds of Anti China forces combined with dirty and evil to become traitors culture.

The control of another characteristic of gang culture is the rigorous. Any a gang has strict control means, in addition to the psychological control, the personal control, organization control, and even violence. Members of his chief, parents, leaders, big brother, to absolute loyalty. The chief, the eldest is above all, all the members do as one pleases, worship as a personal possession of the property. It is in such tight control, every member in the group, no thoughts, only Jordan's will; no personal freedom, only the life of Wang is from. It is by virtue of cult psychological control and the human body, similar to the composition of the underworld organizations, and even openly and as an equal society.

\section{[THREE] Witchcraft Culture to Gang Culture Transition}

The cult of the nature of witchcraft, to cheat for a living, small scam, cheating the color, is Gu world confused people, aspire to political, in an attempt to replace it. So, witchcraft and the transition to organized gang, witchcraft is mixed in the gang culture, formed by worship leader for parents, egomaniacal, mysterious, strict control Gang system. They are controlled by the psychological, mental control to the organization and control of the body. From the original invisible control of a variable and a close physical control. This is the basic law of the development of the cult, but also fully embodies the nature of the cult and the Gang - witchcraft. The cult is a kind of gang culture, like witchcraft culture mixed together the cult. Such cults, linger on faintly in the history. From the Han Dynasty, the "way of the five pecks of rice", "peace”, during the period of the Northern Wei Dynasty, by Qing founded "Mahayana”, and the Southern Song Dynasty until modern iterated through changes, the reproduction of the tribe of the white lotus (Southern Song Dynasty Shaoxing years, later Mao Ziyuan created Bai Lianzong, yuan, Ming and, most recently, the white lotus society throughout the world), and at the beginning of the founding of the people's Republic of China, the appearance of "consistent" and the like secret societies, especially in the near future is in overseas trickster "Falun Gong" is a mixture of the organization of the confraternity of witchcraft culture auto. So to witchcraft inciting audio-visual, assembling a crowd to extort money, then form the antisocial alien force, and storage dispar, seeking. This is the cult of witchcraft culture, gang culture is generated by the poisonous weeds. Whether is witchcraft culture, or gang culture, is clearly decadent culture, is the dregs of the culture in the period of economic development. 


\section{Countermeasures of the Cult}

First of all, for ignorance, deception, strengthening science education. Including modern science and technology, human spirit, religious feelings of education. To fully understand the limitation of human existence, the pursuit of unlimited rationality. The infinite is the ultimate concern beyond cognition, is the ideal pursuit of personality, not God, but not the living god. Knowing this is to identify the cult. Where the cult, there are people who claim to be god. So, where is the earthly world. God poison people, not a cult, is a liar. As for magic, most of the daily life of small tricks, which was easy to identify, but due to the lack of scientific knowledge, self lost, lost the ability to identify. In real life, there are indeed quite a few to nature, society confused and can not grasp their own destiny, grasp the survival situation is not his own and that of witchcraft with a grain of salt. Therefore, strengthening the popularization of science and education, strengthen people's spiritual cultivation, strengthen people's religious feelings, these problems will solve most, giving birth to the cult of the soil will also become barren and lose its stirrings of object.

Second, for closed, open mind. In most of the people being coerced into a cult, often accept less science education or difficult people. In the field of science, he is less permeable. According to the closed psychology, closed psychology, open mind education, more publicity, education, so that these people more contact with society, the influence of social mainstream culture, out of the closed. The so-called "jinzhuzhechi, nearly malignant black", that is the truth.

Third, the transformation of society, but also to transform themselves. Our society is limited, not perfect, also need to reform and evolution, need us to recognize the continuing, long-term struggle, it is the responsibility of the mission of history and science, shoulder heavy responsibilities. We, in the anti cult task, have a long way to go. Not only that, but also to transform themselves. Everyone, especially the government staff, to do a moral model, dedication to the community's example, the implementation of fairness, justice, care, honesty, and serve the people wholeheartedly. As the saying goes: "inequality". The development of the material, but the material can not solve all the problems, mental problems can not be ignored. Me said: "The loss can not be replenished, humanitarian loss in more lack of. Who can more than in the world?” The more development of the material, the better, but not as long as the development, the key is all, to be fair, justice. The development of the material, but not fair, evil cult dregs, also take advantage of a weak point. Now the society does exist in some problems, public opinion is clearly biased: bloody, erotic, rivers and lakes Gang, vulgar rampant, so with advanced culture, and moral self perfection of disposition, cultivate conflict is inevitable to cause many people can not find the destination of the soul and go astray.

Need to be emphasized is, the majority of people living in the real world of limited, hope beyond the limited, grasp the fate, in the spell of some quack, hard to avoid to be deceived. Qing Dynasty called Xu Xinhua said that: "education week, once for the hanging of Li ban, strong flow for the weak in the gully to the Yi!” He was very clear, for most people, focusing on education, focusing on guidance. Education does not follow to go up, once you are in adversity, and imposed a ban, will inevitably lead to two results: the strong flow for the weak in a ditch. In a ditch, is extremely easy for the ulterior motives of the people are confused, once coerced by the strong will not consciously booing, and even become a cult fanatics. These members mostly are weak, or experienced a lot of ups and downs, let them enough understanding of social fairness and justice, the warm feelings of social, to eliminate the effect of the cult, the collapse of the cult is undoubtedly a drastic solution. 


\section{Reference}

XU, K. (1986). Clear barnyard class notes. Beijing: Zhonghua Book Company.

Marx Engels. (1995). Beijing: People’s publishing house.

Ma, T. X. (1998). Give up their own endless possession, go begging. China pauper reform: Theory Weekly.

Ma, T. X. (2006). The history of religious philosophy in China. Beijing: People’s Publishing House. 